\title{
Particle-Associated Viruses in Water: Impacts on Disinfection Processes
}

\author{
MICHAEL R. TEMPLETON*, ROBERT C. ANDREWS, and RON HOFMANN \\ Department of Civil Engineering, University of Toronto, Toronto, Ontario, Canada
}

\begin{abstract}
*Current address: Dr. Michael R. Templeton, Lecturer, Department of Civil and Environmental
Engineering, Imperial College London, South Kensington campus, London SW7 2AZ, United Kingdom. Tel. +44 207594 6099; Fax. +44 207594 6124; E-mail: m.templeton@imperial.ac.uk
\end{abstract}

Submitted for publication in Critical Reviews in Environmental Science and Technology Submitted 15 July 2005

Revised and re-submitted 11 October 2006 


\title{
Particle-Associated Viruses in Water: Impacts on Disinfection Processes
}

\author{
MICHAEL R. TEMPLETON, ROBERT C. ANDREWS, and RON HOFMANN \\ Department of Civil Engineering, University of Toronto, Toronto, Ontario, Canada
}

Address correspondence to Dr. Michael R. Templeton, Lecturer, Department of Civil and Environmental Engineering, Imperial College London, South Kensington campus, London SW7 2AZ, United Kingdom. Tel. +44 207594 6099; Fax. +44 207594 6124; E-mail: m.templeton@imperial.ac.uk

Studies have shown that viruses are frequently attached onto or enmeshed within suspended particles in natural water and wastewater and that this viral particle-association can impede disinfection processes in some circumstances. This article summarizes the current state of knowledge of the occurrence of particle-associated viruses in the aquatic environment and the reported subsequent impacts on disinfection processes. The intention is that this article will help guide future research and aid regulators attempting to address the disinfection of particle-laden waters.

KEY WORDS: drinking water, wastewater, disinfection, particles, viruses. 


\section{INTRODUCTION}

Viruses are frequently found to be attached to solid surfaces such as suspended particles in the aquatic environment. Studies of the disinfection of water have indicated that the presence of suspended particles can sometimes result in reduced virus inactivation when compared to the inactivation achieved in particle-free waters. While drinking water and wastewater treatment often include processes to physically remove particles upstream of disinfection (e.g. coagulation, flocculation, sedimentation, filtration), particles and particle-associated viruses may still penetrate to the disinfection stage of treatment under certain circumstances. For example, this may occur during process upsets, such as periods of sub-optimal coagulation, settling, or filtration, or, during normal operation due to the practical design limitations of the particle removal processes.

This paper begins by providing an overview of viral particle-association, including a discussion of the fundamental mechanisms responsible for virus-particle interactions and a review of case studies that have reported the occurrence of particle-associated viruses in the aquatic environment. This is followed by a summary of the impacts of particle-associated viruses on disinfection processes (chemical disinfection, ultraviolet disinfection). The paper concludes by summarizing the current knowledge and research needs.

\section{VIRUSES IN WATER AND WASTEWATER}

\section{A. Waterborne Viruses - An Overview}


Viruses are sub-microscopic particles ranging in size from 20 to 350 nanometers that infect and sometimes cause disease in humans and other living organisms (e.g. animals, plants, bacteria). A virion, a single infectious viral particle, is composed of a core of nucleic acid (RNA or DNA) surrounded by a protein coat called a capsid. The protein coat protects the virion from adverse environmental conditions, while the nucleic acid core is what grants infectivity to the virion (Bitton, 1980a). The core DNA or RNA may contain one or two strands. In some viruses the capsid is surrounded by an envelope that contains lipoproteins or lipids (Bitton, 1980a).

Viruses are fundamentally different from all other microorganisms in that they are incapable of replicating or adapting to environmental conditions outside of a living host. A viral particle in the environment eventually loses its infectivity with the passage of time and with exposure to inactivating agents (e.g. sunlight, elevated temperatures) (Carter 2005). The interaction of viruses with surfaces such as fecal matter, colloidal clays, soils, and biological and chemical floc particles can enhance virus survival in the environment by protecting them from environmental factors and can also play a role in the effectiveness of water treatment processes (e.g. disinfection) against viruses (Gerba, 1984).

The principal viruses of public health concern in potable water are the enteric viruses, characterized by their ability to infect tissues in the throat and gastrointestinal tract, although they are capable of replicating in other organs of the body also (Carter, 2005). There are over 100 enteric viruses which are excreted in human feces and can be potentially transmitted by water, including hepatitis A, Norwalk-type viruses, rotaviruses, adenoviruses, and reoviruses (Gerba, 1984).

Waterborne outbreaks of viral illness are difficult to recognize due to the inadequacy of epidemiological methods for detecting low-level transmission of these diseases through water. 
Another complication is that many viruses cause unapparent or latent infections (Goyal, 1983). As such, the true prevalence of waterborne viral outbreaks is unknown. A person coming in contact with contaminated water may ingest a virus that may actively multiply in the gastrointestinal or respiratory tracts and yet the person may not show signs of overt illness. Such a person will, however, serve as a carrier of viral infection and will continue shedding the viruses in secretions and excretions. While the symptoms most commonly attributed to enteric viral infections are gastroenteritis and diarrhea, some enteric viruses are also responsible for respiratory symptoms, central nervous system infections, hepatic infections, muscular syndromes, and have been implicated in some forms of diabetes and chronic fatigue syndrome (Federal-Provincial-Territorial Committee on Drinking Water, 2003). It is only when water is grossly contaminated and a large number of people come in contact with the water at the same time and become ill at the same time that epidemiological proof of waterborne viral illness can be established (Goyal, 1983). The development of molecular techniques (e.g. reverse transcriptase polymerase chain reaction, RT-PCR) and immunological assays for virus identification and enumeration has been an important advance in the epidemiological study of waterborne viral illness (Wyn-Jones and Sellwood, 2001).

\section{B. Bacteriophages as Model Viruses in Treatment Studies}

Routine monitoring of human viruses is not practical due to their low numbers in contaminated waters. Source water samples of 10 to $1,000 \mathrm{~L}$ must be concentrated in order to detect human viral pathogens. Also, the infectivity of some enteric viruses can be difficult to assess via cell culture and can require long analysis times (Wyn-Jones and Sellwood, 2001). Due 
to these practical difficulties in measuring human enteric viruses in the environment, bacteriophages are often used as surrogates for human viruses.

Bacteriophages are viruses that infect bacteria via receptor sites on the host cell surface. Coliphages are bacteriophages that infect coliform bacteria (e.g. Escherichia coli) specifically. Icosahedral coliphages such as MS2 and f2 (versus larger tailed T phages) are often used to represent human enteric viruses due to their similar size $(20-30 \mathrm{~nm})$ and structure and because they share similar survival characteristics when discharged into the aquatic environment. Bacteriophages are also non-pathogenic and can be cultivated overnight. A number of researchers have commented on the ability of indigenous bacteriophages (e.g. F-specific RNA phages, including MS2) to serve as indicators of viral pollution in fecally contaminated water (Kott et al., 1974; Havelaar et al., 1986; Lewis, 1995; Grabow, 2001; Sundram et al., 2002), although there are not necessarily always strong correlations between bacteriophage concentrations and concentrations of pathogenic viruses (Goyal, 1983; Grabow, 2001). Bacteriophages have been used as model viruses in a number of contexts: as indicators of the presence of human viruses in natural waters and wastewater, as model viruses in particle adsorption studies, and as model viruses in treatment studies (i.e. coagulation, filtration, chlorination, UV disinfection studies) (Table 1). An excellent summary of the applications of bacteriophages as model viruses is provided in Grabow (2001).

\section{PARTICLES IN WATER AND WASTEWATER}

\section{A. Types and Origins of Particles}


Particle sizes are commonly termed in microns $\left(10^{-6} \mathrm{~m}=1 \mu \mathrm{m}\right)$ in water and wastewater treatment. Particles to be removed from a raw water supply typically range in size from up to 100 $\mu \mathrm{m}$ in size and visible to the naked eye, down to nanometer-size particles viewed only by electron microscopy. Colloidal particles comprise a large portion of the turbidity-causing substances in water, although there are different size range definitions of the term 'colloid', including 0.001-1.0 $\mu \mathrm{m}$ (Matson, 1987), 0.001-10 $\mu \mathrm{m}$ (USEPA, 1999) or any particle with diameter $<10 \mu \mathrm{m}$ (McCarthy and Zachara, 1989). (It should be noted that particle sizes are typically described in terms of diameters, however in reality not all particles are spherical.) The small size of colloids renders them unsettleable and mobile in a water column and their large surface area and ion exchange capacity make them strong adsorbents. As such, colloids are of special interest in the environmental sciences for their role in the transport of adsorbed contaminants (including pathogens) in aquatic environments (McCarthy and Zachara, 1989; USEPA, 1999).

Suspended particles in water can consist of inorganic and organic particles. Inorganic particles are produced by the natural weathering of minerals and may include iron oxides, silts, and clays (e.g. kaolinite, bentonite). The size of clays, metal oxides, and other particles originating from mineral sources typically varies from several nanometers to several microns in diameter. Clay is usually defined on a particle-size basis, the upper limit being $2 \mu \mathrm{m}$ in diameter (National Research Council, 1977; McCarthy and Zachara, 1989). Because of their occurrence in soils, streams, and other water bodies such as lakes and fish ponds, clay minerals are closely associated with microorganisms in their natural habitat (Bitton et al., 1972). Both clays and organic particles have large surface areas and strongly adsorb ions, polar and nonpolar molecules, and biological agents (Bitton et al., 1972). Naturally-occurring and synthetic organics 
found in surface waters can include organic matter associated with soil particles, organic particles from sewage and industrial treatment plant effluent, plant and animal debris, organic colloids, and microorganisms (Rao, 1987).

Besides size and composition classifications, colloids can also be described based on their affinity for water. Clay and many inorganic particles behave as hydrophobic colloids while most organic particles are hydrophilic (Hoff and Akin, 1983).

\section{B. Model Particles Used in Treatment Studies}

Due to the heterogeneity in content, size, and surface properties of particles found in natural waters, research studies often create controlled experimental conditions in which model particles with known properties are added to particle-free water. Dry dog food, fecal homogenates, and wastewater activated sludge particles have been used as model organic particles. Similarly, several types of clay have been used as surrogate inorganic colloids; montmorillonite, kaolin, and bentonite have been commonly used in studies of virus-particle interactions. A summary of particle types considered in previous virus-particle adsorption studies is given in Table 2 .

C. Parameters Used to Express Particulate Content of Water and Wastewater

Turbidity is a standard process control parameter used in drinking water treatment. Turbidity measurements are rapid, relatively inexpensive, and can be performed continuously using online detectors. Turbidity measurements in drinking water are essential indicators of 
water quality because particles may act as carriers for a variety of materials such as pesticides, heavy metals, and microorganisms (including viruses) (LeChevallier et al., 1981). However, turbidity does not give complete information about the size, number, mass, or type of particles that are either scattering or absorbing light. Further, turbidity may vary in its nature and composition from region to region, and since it is an optical property of a suspension, its measurement will be influenced by particle size, shape, number, and instrument characteristics (LeChevallier et al., 1981). In wastewater treatment, total suspended solids measurements are typically used to quantify particulate content. This parameter requires drying and massing of water samples and cannot be measured in situ.

While turbidity and suspended solids may be used as basic indicators of the removal of a wide variety of particles in water treatment, particle counts (e.g. \# of particles per unit volume, usually $\mathrm{mL}$ ) can be a more informative measurement (Hoff and Akin, 1983). Current online particle counters are typically limited to measuring particles larger than approximately $1 \mu \mathrm{m}$ in diameter (with a spherical particle assumption), so smaller colloids are not detected.

Studies have generally shown that a reduction of turbidity is a preventive measure to minimize the protective effect of particles during disinfection (Bitton, 1980b). However, the reduction of turbidity and particle counts is not necessarily indicative of the removal of pathogens such as Cryptosporidium by water treatment processes (LeChevallier et al., 1991; Nieminski and Ongerth, 1995).

\title{
IV. PARTICLE-ASSOCIATED VIRUSES IN WATER AND WASTEWATER
}

\author{
A. Mechanisms of Virus-Particle Interaction
}


There are well-established theories that describe colloidal particle behavior in a dispersion medium, and these apply to viruses as well (Gerba, 1984). However virus adsorptive behavior also depends greatly upon the virus being studied and specifically the different surface charges on the virion capsid coat. Most viruses have coats composed of protein polypeptides that contain amino acids such as glutamic acid, aspartic acid, histidine, and tyrosine. These amino acids contain weakly acidic and basic groups (i.e. carboxyl and amino groups), which upon ionization give the viral capsid an electrical charge (Fuhs and Taylor, 1982). Typical charging reactions are:

$$
\begin{gathered}
-\mathrm{CO}_{2} \mathrm{H} \leftrightarrow-\mathrm{CO}_{2}^{-}+\mathrm{H}^{+} \\
-\mathrm{NH}_{3}^{+} \leftrightarrow-\mathrm{NH}_{2}+\mathrm{H}^{+} \\
-\mathrm{C}_{6} \mathrm{H}_{4} \mathrm{OH} \leftrightarrow-\mathrm{C}_{6} \mathrm{H}_{4} \mathrm{O}^{-}+\mathrm{H}^{+}
\end{gathered}
$$

Each ionizing group in the polypeptide has a characteristic dissociation constant. The variation of dissociation constants among the various polypeptides ensures that most viruses have net charges that vary continuously with $\mathrm{pH}$ (Fuhs and Taylor, 1982). At a characteristic $\mathrm{pH}$, defined as the isoelectric point $(\mathrm{pI})$, ionization is such that the virion exists in a state of zero net charge. Viruses will be positively charged below their isoelectric point and negatively charged above it. Isoelectric points of several viruses have been reported in the literature (Table 3 ). In general, high $\mathrm{pH}$ favors free virus and low $\mathrm{pH}$ favors adsorbed virus, although isoelectric points of both the virus and surface play roles in this interaction (Gerba, 1984). 
The variation in virus adsorption observed with soils, sludge, and estuarine sediments can also be attributed to differences in the adsorbent (i.e. particle) isoelectric points (Table 4). Muck and other soils high in organic matter are generally poor absorbers of virus (Fuhs and Taylor, 1982). Potential adsorbents of viruses in natural waters include sand, pure clays (e.g. montmorillonite, illite, kaolinite, bentonite), bacterial cells, naturally occurring suspended colloids, and estuarine silts and sediments.

The role of adsorbent charge in virus adsorption has been considered in detail for soils, for filters used to concentrate viruses from water, and for metal surfaces. Knowing the net charge on the virus and adsorbent can aid in predicting and controlling virus adsorption to surfaces. When the electrostatic components of adsorption are considered by themselves, solids that have high isoelectric points are better virus adsorbents than those with low values. As such, the following general series of adsorbent effectiveness can be expected (Gerba, 1984):

$$
\text { Metals (strong) }>\text { Sulfides }>\text { Transition Metal Oxides }>\mathrm{SiO}_{2}>\text { Organics (weak) }
$$

Further, some particles, such as clays, may have surfaces that have a heterogeneous distribution of charges. Therefore, viruses with different isoelectric points may also be expected to adsorb to different regions of the same clay (Lipson and Stotzky, 1987).

In addition to electrostatic interactions, hydrophobic residues may play a role in the adsorption of viruses to particulate matter (Wait and Sobsey, 1983). Mamane-Gravetz and Linden (2005) described the role of hydrophobicity in the clumping and particle-association of bacterial spores. To minimize the disruptive effects on its hydrogen-bonded network, water forces hydrophobic groups together. This attraction allows a weak van der Waals bonding 
interaction to take place. The potential for hydrophobic interactions is supported by the finding of nonpolar groups on the surface of virus particles (Ellender et al., 1987). The nature of hydrophobic groups on suspended particles is unknown but is consistent with the observation that soluble proteins and other natural substances bind to suspended matter and contain hydrophobic residues.

Since the adsorption of viruses onto particles is therefore complex and dependent on a number of factors (e.g. isoelectric point of the virus, isoelectric point of the particle, hydrophobicity), empirical observations have provided much of the understanding of the adsorption behavior of viruses. For example, in a study of adsorption of various types and strains of viruses to different soil types, Gerba (1984) used factor analysis to classify viruses and phages into three broad groups according to their attachment patterns (Table 5). Viruses and phages that were grouped together attached (or did not attach) to similar types of soils to similar degrees.

The location and orientation (i.e. head- or tail-attached to particle) of adsorbed viruses on clay minerals and other negatively charged particles also depends on the type of adsorbent and the type of virus (Table 6) (Lipson and Stotzky, 1987). Coliphage T1, for example, adsorbs by an edge-to-edge arrangement for kaolinite and montmorillonite as well as by a face-to-face arrnagement for montmorillonite only. Electrostatic forces cause adsorption of the positively charged tail fibers of coliphage T1 to negatively charged sites on the clays, since the tail fibers of most tailed phages are positively charged (Lipson and Stotzky, 1987).

Stagg et al. (1977) reported that MS2 (a tailless phage) was protected from the virucidal action of chlorine when adsorbed on montmorillonite, but Boardman and Sproul (1977) did not observe this protective effect on coliphage T7 associated with kaolinite. Lipson and Stotzky 
(1987) propose that if coliphage T7 was adsorbed on the kaolinite by a tail-to-face mode of attachment, its head may have been exposed to the inactivating effect of chlorine.

Nonlipid and lipid-containing viruses (e.g. coxsackievirus, echovirus, adenovirus) have also been found to be protected against inactivation during transport by the use of a medium containing bentonite (Lipson and Stotzky, 1987). Electron microscopy has shown that coxsackievirus A9 is adsorbed to the bentonite by a face-to-face attachment (Table 6). Electron microscopy has also indicated that the adsorption of poliovirus type 1 on montmorillonite occurs at the edge surfaces of the clay, suggesting that adsorption results from electrostatic attraction between the net negatively charged virus and the net positively charged edges of the clay (Lipson and Stotzky, 1987).

In addition to these fundamental mechanisms by which viruses become attached to particles in the aquatic environment, viruses may also be discharged into natural waters already attached to or occluded within solids. For example, studies have shown that viruses are already associated with fecal material and other particles in wastewater (Hejkal et al., 1979; Hejkal et al., 1981). Further, the application of coagulants (e.g. alum) in water treatment for particle removal encourages virus association with floc particles (Gerba, 1984; USEPA, 1999; Templeton et al., 2005).

Dissolved constituents in water can also impact viral particle-association, For example, Quignon et al. (1999) reported that salts favor virus association with particles, with multivalent cations being more efficient than monovalent ones. Also, visible flocculation of solids is not a prerequisite for significant virus association, meaning that viruses can associate with particles that are smaller than those visible to the naked eye (Schaub and Sagik 1975). 


\section{B. Case Studies of the Occurrence of Particle-Associated Viruses}

A number of studies have shown that viruses will preferentially adsorb onto particles and that particle-associated viruses remain viable longer than dispersed (free-floating) viruses. For example, Rao et al. (1984) investigated the distribution and quantity of enteroviruses among water, suspended solids, and sediments in the estuary of Galveston Bay, Texas. Virus was found most often attached to suspended solids: $72 \%$ of the samples containing solids contained viruses, while only $14 \%$ of water samples without solids yielded viruses. When associated with solids, poliovirus and rotavirus retained infectivity for 19 days, while the same viruses remained infectious for only 9 days when freely suspended in seawater. Similarly, Lipson and Stotzky (1985) studied adsorption and desorption of reovirus from kaolin and montmorillonite clay. The infectivity of the adsorbed and bound virus was retained. Reovirus was detected after 18 and 22 weeks in distilled and synthetic estuarine waters amended with kaolinite and montmorillonite, respectively, whereas the virus was not detected after 7.5 weeks in either water in the absence of clay.

However, the presence of suspended particles in a water sample does not necessarily ensure that viruses will become associated with them and hence be subsequently protected from environmental factors (Babich and Stotzky 1980; Quignon et al. 1999). As described earlier, virus attachment to particle surfaces is highly dependent on the type of particle and type and strain of virus. For example, Meschke and Sobsey (1998) considered the adsorption of Norwalk virus, poliovirus 1, and MS2 coliphage to six soils suspended in wastewater (kaolinite, bentonite, clay-loam, organic muck, sand-loam, and coarse sand). Norwalk virus was less sorptive than poliovirus and more sorptive than MS2. Relative virus adsorption among soils was similar for all 
three viruses, with viruses most adsorbed by clays and least adsorbed by sand and organic soils. All three viruses were strongly adsorbed by clay-loam. Moore et al. (1975) demonstrated that T2 and $\mathrm{f} 2$ readily associated with the clays, while $\mathrm{T} 7$ and poliovirus adsorbed equally to both organic and inorganic particles. Gerba et al. (1980) considered poliovirus 1, echovirus 1, 7, 29, and coxsackievirus B3 and B4 and their interactions with activated sludge, estuarine sediment, and sandy loam soil. The greatest variability in adsorption of the different viruses was seen in their behavior toward the soil samples and the least with the estuarine sediments. The authors concluded that the differences in adsorptive behavior were due to differences in the isoelectric points $(\mathrm{pI})$ of the different viruses studied.

It should also be noted that in some cases, viral particle-association can actually enhance virus inactivation, such as in virus adsorption to titanium dioxide particles (Lee et al., 1997; Koizumi and Taya, 2002).

\section{METHODS FOR ENUMERATING PARTICLE-ASSOCIATED VIRUSES}

Failure to account for particle-associated viruses results in underestimation of the true virus concentration in environmental samples (Moore et al., 1975; Wellings et al., 1976; Bixby and O'Brien, 1979; Block, 1983; Farrah and Schaub, 1983; Rao and Bitton, 1987; Rao 1987). Methods for enumerating solids-associated viruses have been used in studies of viruses within estuarine sediments, attached to suspended particles, and adsorbed to soil particles. These methods typically involve addition of a protein-rich eluent (e.g. beef extract, tryptose broth), which disrupts electrostatic bonds between the virus and particle, in combination with application of physical forces intended to shear particle surfaces, such as by sonication, blending, 
mixing, or vigorous shaking. Wait and Sobsey (1983) speculate that the action of beef extract as a viral eluent may result from the phenomenon through which soluble organic substances reduce the extent of adsorption of viruses to surfaces. This phenomenon is hypothesized to be due to competition between soluble organic compounds and viruses for specific adsorption sites on surfaces. Smaller protein molecules present in beef extract may intercalate between larger virions and their adsorption sites on sediment particles and reduce the strength of their mutual attractive electrostatic forces. Further, in general low $\mathrm{pH}$ favors adsorption while high $\mathrm{pH}$ results in elution (Melnick, 1987); as such, many of the elution methods involve raising the $\mathrm{pH}$ to 9-11. Different elution methods have shown varying degrees of success in terms of virus recovery, with the effectiveness of the method related to both the eluent and the type of solid being considered (Rao and Bitton, 1987). A summary of previous virus elution methods used for a variety of applications is given in Table 7 .

Analogous methods for enumerating particle-associated bacteria (e.g. bacteria associated with wastewater sludge particles) have also been developed and involve application of physical shear forces and chemical elution, similar to the virus recovery techniques described above. Parker and Darby (1995) investigated the effectiveness of various blending and sonication techniques for extracting particle-associated coliforms from secondary effluent samples. The amount of shielding from ultraviolet disinfection afforded these coliforms by the particles was then assessed. Blending samples for 1.5 minutes at $19,000 \mathrm{rpm}$ in a mixture of elution chemicals resulted in the highest recovery of particle-associated coliform, as detected by the multiple tube fermentation (MTF) method. The authors reported that particle-association and shielding of coliforms significantly affected accurate measurement of coliform density in secondary effluent 
using the standard MTF test and that many more coliforms are present in disinfected secondary effluents than are measured by standard enumeration procedures.

In a similar study, Borst and Selvakumar (2003) investigated the effects of blending and chemical addition before analysis of the concentration of microorganisms in stormwater runoff to determine whether clumped or particle-associated organisms were present. There was an increase in organism concentrations after blending the samples at 22,000 rpm (for one or two minutes) with or without the chemical mixture. The authors emphasized that the standard methods used in monitoring and research programs to quantify the microorganism concentration do not measure either clumped organisms or organisms associated with particles.

It is important to note that these enumeration methods do not yield information on whether the previously solids-associated viruses were completely enmeshed within the particle or merely surface attached. Therefore, while a large percentage of a virus population may be measured as being particle-associated, it does not necessarily follow that all of these viruses will be effectively shielded from disinfection.

\section{IMPACTS OF PARTICLE-ASSOCIATED VIRUSES ON DISINFECTION PROCESSES}

\section{A. Brief Overview of Disinfection Processes and Mechanisms}

The maintenance of free chlorine residuals is the principal means by which drinking water utilities ensure adequate disinfection. Other chemical disinfectants in common use in the drinking water industry include chloramines, chlorine dioxide, and ozone. Since the 1998 discovery that ultraviolet (UV) light can inactivate the chlorine-resistant protozoan pathogen 
Cryptosporidium parvum at economical doses (Clancy et al., 1998), UV disinfection is also now considered a viable primary disinfectant of drinking water in North America. In wastewater treatment, chlorination and UV disinfection are commonly applied.

All disinfectants rely on the ability of either chemical disinfectant molecules or highenergy photons (in the case of UV disinfection) to come in contact with the target organism. Chemical disinfectants inactivate organisms by either oxidation or rupture of the cell wall, leading to consequent cell disintegration, or by diffusion into the cell and subsequently interfering with cellular activity. The inactivation mechanism of UV disinfection proceeds via the formation of pyrimidine dimers in the DNA/RNA of the target organism, which prevents replication (Giese and Darby, 2000; Durbeej and Eriksson, 2003). If contact between the disinfecting agent and the organism is reduced or prevented altogether, such as if the organism is occluded within a particle or within a microbial aggregate, then disinfection may be impeded.

\section{B. Disinfection Kinetics - Theoretical Impact of Particle-Associated Microorganisms}

Chemical disinfection (e.g. chlorination) is quantified in terms of the product of the disinfectant dose applied (mg/L) and the contact time (minutes) (USEPA, 1989). This product is called CT, with units of $\mathrm{mg} \cdot \mathrm{min} / \mathrm{L}$. The CT required to achieve a certain $\log$ inactivation of a target organism via chlorination, the most common chemical disinfectant, is dependent on the $\mathrm{pH}$ and temperature of the water, since chlorination efficiency increases with reduced $\mathrm{pH}$ and increased temperature. For UV disinfection, in which no chemical dose is applied, the disinfectant dose is expressed as the product of UV intensity, or fluence rate $\left(\mathrm{mW} / \mathrm{cm}^{2}\right.$ or $\left.\mathrm{W} / \mathrm{m}^{2}\right)$, and time (seconds). The product is called UV dose or fluence, with units of $\mathrm{mJ} / \mathrm{cm}^{2}$ or J/m². 
Microbial inactivation is generally be expected to increase in a log-linear fashion as the disinfectant dose increases, as per first-order Chick-Watson kinetics described by the following equation:

$$
N_{f}=N_{i} e^{-k D}
$$

where $\mathrm{N}_{\mathrm{f}}=$ number of surviving organisms (e.g. PFU/mL)

$\mathrm{N}_{\mathrm{i}}=$ inital number of organisms prior to disinfection (e.g. PFU/mL)

$\mathrm{k}=$ inactivation rate coefficient (e.g. $\mathrm{L} / \mathrm{mg} \cdot \mathrm{min}$ for chlorination)

$\mathrm{D}=$ disinfectant dose (e.g. $\mathrm{mg} \cdot \mathrm{min} / \mathrm{L}$ for chlorination)

However, microbial inactivation does not always conform to log-linear or first-order kinetics. Under optimal chemical and physical conditions, maximum disinfection efficiency is reached when the disinfectant agent has unhindered access to the target organism. However particulate matter may interfere with this process, either by acting chemically to create a disinfectant demand or by physically shielding the organism from the disinfectant (Haas et al., 1996; Stewart and Olson, 1996), which can cause so-called "tailing" of inactivation curves (i.e. reduced inactivation) at elevated disinfectant doses. Further, it has been speculated that small organisms (such as viruses) may be afforded much greater disinfection protection than larger organisms at lower turbidity conditions (Stewart and Olson, 1996) and by smaller particles (Emerick et al., 2000).

C. Case Studies of the Chemical Disinfection of Particle-Associated Viruses 
It is well known that dispersed (free-floating) enteric viruses in water and wastewater can be effectively controlled by the addition of adequate concentrations of free chlorine or other disinfectants (e.g. Shin and Sobsey 1998; Thurston-Enriquez et al. 2003). However, several studies have concluded that viral particle-association has an adverse effect on chemical disinfection. For example, Stagg et al. (1977) showed that bacteriophage attached to clay are more resistant to free chlorine $(\mathrm{HOCl})$ than are freely suspended phages - for equivalent $\mathrm{HOCl}$ concentrations, clay-associated phage required about twice the time that free suspended phages required for loss of $99 \%$ of the initial virus titer. Also, Hejkal et al. (1979) reported that poliovirus that is closely associated with or occluded within small fecal particles is protected, with a fourfold increase in combined residual chlorine required to achieve the same degree of inactivation for occluded virus as for free virus.

In contrast, some studies have showed that the presence of particles does not affect chemical disinfection. Boardman and Sproul (1977) reported that inorganic particles including alum, calcium carbonate, and kaolin did not interfere with tailed coliphage T7 inactivation by chlorine. However these authors suggested that protection from disinfection would occur only after total encapsulation of the virus with the particulate matter and Lipson and Stotzky (1987) suggested that the manner in which the coliphages T7 attached to the particles in this study may not have been conducive to protection from chlorine. Boyce et al. (1981) considered the inactivation of poliovirus, coxsackievirus $\mathrm{A} 9$, and fr bacteriophage by ozone in the presence of bentonite clay. While $\mathrm{f} 2$ bacteriophage was inactivated at a slightly slower rate than the freely suspended phage, poliovirus and coxsackievirus were provided no protection from ozone by 1-5 NTU levels of bentonite. The authors conceded that while ozone demand-free bentonite clay particles were unable to protect associated viruses, it is possible that particles of different 
composition might have led to a different result. Similarly, Barbeau et al. (2004) reported little or no protection of phage MS2 provided by kaolin particles, up to a concentration of $5 \mathrm{mg} / \mathrm{L}(\sim 5$ NTU). The authors concluded that the role of turbidity is most likely dependent on the origin of the turbidity, as related to its capacity to interact with microorganisms.

Some studies have taken active steps to ensure viral particle-assocation (e.g. alum coagulation) prior to applying disinfection rather than simply adding the virus and particle into a water matrix. This step may represent the impact of upstream coagulation processes in conventional drinking water treatment, for example. Ohgaki and Mongkonsiri (1990) showed that alum floc particles protected $\mathrm{Q} \beta$ from free chlorine when the phage were entrapped (flocculated) within particles or when they were adsorbed onto the surface of the floc.

From these previous studies of the impact of viral particle-association on chemical disinfection efficiency, it can be concluded that whether an effect is measured or not depends heavily on the types of particle and virus being studied and may not be easily generalized to other viruses and particles. Further, while protection of viruses against inactivation by chemical disinfectants has been demonstrated with various added particle types, these create artificial conditions that may not always reflect "real world" particle conditions (Gerba, 1984).

\section{Cases Studies of the Inactivation of Particle-Associated Viruses by UV Light}

There have been a limited number of studies on the ability of UV light (either from sunlight or UV lamps) to inactivate particle-associated viruses. Bitton et al. (1979) reported that solar radiation has an inactivating effect on poliovirus type 1 but that nontronite clay $(500 \mathrm{mg} / \mathrm{L}$ ) displayed a protective effect against virus inactivation by UV light. The value for $90 \%$ virus 
inactivation was 75 minutes in groundwater and 163 minutes in groundwater amended with clay. The mean light intensity considered in this study was reported as $0.647 \mathrm{cal} / \mathrm{cm}^{2} \mathrm{~min}$, however the wavelengths of the UV light were not stated and the intensity value that was reported may have been the sum of intensities from multiple wavelengths.

Templeton et al. (2005) reported that under elevated particle concentrations (70-100 NTU), humic acid floc particles and activated sludge particles can enmesh and protect viral surrogates (MS2 coliphage, bacteriophage T4) from UV doses (254 nm), while inorganic kaolin clay particles at the same turbidity levels provide no protection. The UV dose was normalized to take into account the UV absorbance of the particles. The organic particles providing shielding in this study had mean particle diameters smaller than $2 \mu \mathrm{m}$. While the particle concentrations were much higher than would typically be encountered in water treatment, the study showed that particle composition is an important factor in the protection of particle-associated viruses from UV light.

Much research has been done on the UV disinfection of particle-associated bacteria in wastewater. In the early applications of UV disinfection to wastewater, researchers recognized relationships between particle loadings and the survival of bacteria (Oliver and Cosgrove, 1975; Qualls et al., 1983; Whitby et al., 1984; Qualls et al., 1985). Since many of the same principles apply to the UV disinfection of particle-associated viruses, it is worth considering the findings from studies of the UV disinfection of particle-associated bacteria.

Particles larger than approximately $7-10 \mu \mathrm{m}$ are able to enmesh and protect coliform bacteria from UV light (Qualls et al., 1983; Emerick et al., 2000; Jolis et al., 2001; Wright et al., 2002). Emerick et al. (2000) derived an equation for describing the inactivation of particle- 
associated coliform bacteria in wastewater secondary effluent exposed to UV disinfection, shown below:

$$
N(t)=N_{D}(0) e^{-k I t}+\frac{N_{P}(0)}{k I t}\left(1-e^{-k I t}\right)
$$

where $N(t)=$ total number of measured coliforms at time $t$

$$
\begin{aligned}
& N_{P}(0)=\text { total number of particles containing at least one coliform at time } t=0 \\
& N_{D}(0)=\text { total dispersed (free-floating) organisms at time } t=0 \\
& k=\text { inactivation rate coefficient }\left(\mathrm{cm}^{2} / \mathrm{mJ}\right) \\
& I=U V \text { intensity }\left(\mathrm{mW} / \mathrm{cm}^{2}\right) \\
& t=\text { exposure time (seconds) }
\end{aligned}
$$

The critical particle size capable of completely shielding viruses is expected to be smaller than that observed for bacteria and it is possible that a larger fraction of the virus associated with particles would be shielded from UV light (Emerick et al., 2000). The findings of Templeton et al. (2005) support this hypothesis that particles that are smaller than the size cutoff for the protection bacteria from UV disinfection $(7-10 \mu \mathrm{m})$ can potentially shield viruses from UV light.

Bitton et al. (1972) also recognized that the particle type, and specifically the UVabsorbing content of the particles, is crucial in the survival of particle-associated bacteria during UV disinfection. This study examined different clay minerals and humic acid and determined that the survival of Klebsiella aerogenes exposed to UV light was directly correlated with the specific absorption in the UV range $(254 \mathrm{~nm})$ of the clay minerals and humic acid under study. The clays with the highest absorption values (nontronite and ferric sulfate, both of which are high in trivalent iron) led to more survival than those with lower absorption values (e.g. kaolinite, hectorite). The authors explained that because of their larger particle size, clay 
minerals are better light scatterers than the humic acid. However, on the basis of suspension concentration, the humic acid, which had higher UV absorption than all the clay minerals, was more efficient in protecting the bacteria from UV light than any of the clay minerals studied.

Particles containing UV-absorbing iron have also been shown to have an impact on UV disinfection. Cairns et al. (1993) reported higher numbers of surviving coliforms at higher ironto-suspended solids ratios and speculated that it could be due to the particles having lower UV transmittance as a result of UV absorption of iron itself or due to a more compressed packing of the iron-rich particles, or due to a combination of these factors. Particles with higher iron content in this study required higher UV doses to achieve the same level of disinfection at the same suspended solids concentration, even when the UV absorbance of the solution was taken into account in the UV dose calculation. Similarly, iron oxide precipitate particles in air-oxidized groundwater samples with elevated iron content can protect bacteriophages from UV light to a measurable degree (Malley et al., 2001; Templeton et al., 2006).

Studies have also shown that relatively thin layers of UV-absorbing organic material can dramatically reduce incident UV light. Loge et al. (1999) reported that the UV absorbance (254 $\mathrm{nm}$ ) of wastewater solids can range from 3,300 to $569,000 \mathrm{~cm}^{-1}$, meaning that UV light diminishes by two orders of magnitude within the first 0.04 to $6 \mu \mathrm{m}$ of wastewater solid material. Scott et al. (2005) reported that extracellular polymeric substances (EPS) absorb UV light at 254 $\mathrm{nm}$ with an absorbance of $250 \mathrm{~cm}^{-1}$ and that EPS may therefore also prevent the penetration of UV light through microbial floc.

It is important that UV studies considering particle-laden waters (e.g. wastewater and some unfiltered drinking waters) must take into account the light that is reflected off of particles when measuring the UV absorbance of the water (Christensen and Linden, 2001; Mamane- 
Gravetz and Linden, 2004). This can be accomplished using a spectrophotometer mounted with an integrating sphere sensor. A spectrophotometer without such a sensor will only measure the light that passes directly though the water at $180^{\circ}$ to the incident light beam, thereby overestimating the true absorbance of the water sample (i.e. since reflected UV light can still disinfect).

E. Comparisons of UV Light and Chlorine for the Inactivation of Particle-Associated Viruses

Two recent studies have compared the ability of chlorine and UV light to penetrate particles and inactivate organisms. Dietrich et al. (2002) modeled the diffusion of a chemical disinfectant into wastewater particles as a serial two-step process involving transport through a macroporous network of pathways to micropores that lead into dense cellular regions. While ultraviolet (UV) light penetration into wastewater particles is limited primarily to macropores, resulting in a residual concentration of targeted organisms in post-disinfected effluents that reflects the number of organisms embedded in the dense cellular regions of particles, chlorine penetrates into both the macroporous and microporous network of pathways.

Ormeci and Linden (2002) conducted an experimental study which complemented the mathematical modeling of Dietrich et al. (2002). This study compared the disinfection effectiveness of UV light and free chlorine for naturally occurring particle-associated coliforms and dispersed coliforms in wastewater. Both UV and chlorine were effective for inactivation of dispersed coliforms. Particle-associated coliforms survived at UV and chlorine disinfection doses typically applied in a wastewater treatment plant. The inactivation rate of dispersed coliforms was greater than the inactivation rate of particle-associated coliforms under UV or chlorine 
disinfection. Under prolonged contact times, chlorine was more effective for inactivation of particle-associated coliforms than UV light, which agrees with the Dietrich et al. (2002) explanation. The authors concluded that although UV disinfection is an effective technology for the inactivation of non-particle-associated microbes, complete inactivation of pathogens in the presence of particles may not be practical.

The proposed advantage of chlorine over UV disinfection due to its ability to penetrate the micropores of particles after prolonged contact times may be even more important with respect to the inactivation of viruses, because of their much smaller size relative to bacteria and hence their ability to have access to and be shielded by much smaller pore spaces. While studies have reported that chlorination efficiency is impeded due to viral particle-association (described above), it is possible that under extended contact times chlorine may eventually inactivate these occluded viruses. Further research is required to investigate this hypothesis.

\section{F. Impacts of Turbidity on the UV Disinfection of Phage MS2}

Two recent studies have considered the inactivation of phage MS2 in turbid drinking waters (Passantino et al., 2004; Batch et al., 2004). Passantino et al. (2004) reported that the levels of turbidity and algal cells typically present in unfiltered drinking water supplies do not negatively affect the ability of UV light to effectively inactivate seeded MS2. Possible explanations for this are that the turbidity tested were too low or that the MS2 did not associate with the particles, leaving the phage free-floating and susceptible to UV disinfection. Similarly, Batch et al. (2004) evaluated the effect of water quality (turbidity, particle count, particle size, absorbance) on inactivation of MS2 in 17 filtered waters. Turbidities ranged from 0.01 to 3.5 
NTU. There was no statistically significant decrease in inactivation of MS2 with increasing turbidity over the range of natural turbidities or particle counts evaluated for all UV doses. In both Passantino et al. (2004) and Batch et al. (2004), phage MS2 was spiked into the waters without steps taken to associate the phage with particles, such as by coagulation. As such, these studies can only suggest the impact of turbidity on dose response as it relates to the impact of UV light scattering by particles, rather than particle-association or clumping of microorganisms (Swaim et al., 2005).

\section{PARTICLE CHARACTERISTICS INFLUENCING DISINFECTION PROCESSES}

Organic particles can negatively impact the chemical disinfection of viruses, while only some inorganic particles have an effect (Gerba, 1984). This is likely due to the disinfectant demand exerted by the particle on the disinfectant molecules as they penetrate the particle surface (Dietrich et al., 2002). Similarly, Bitton et al. (1972) concluded that survival of bacteria exposed to UV light was directly correlated to the UV absorbance of the particle with which the bacteria were associated, and Templeton et al. (2005) showed the same for the UV inactivation of particle-associated viruses. In addition to the disinfectant demand of the particle, particle structure and porosity also plays a role in the shielding of organisms from disinfection. Dietrich et al. (2002) showed that the microporous structure of particles determines resistance to inactivation by chlorine and UV of enclosed bacteria.

Turbidity is not always an ideal measure of the ease or difficulty for which a water can be disinfected, since interference with disinfection can depend as much on the type of particles present than the actual turbidity level (Boyce et al., 1981). For example, Passantino et al. (2004) 
showed that the UV dose-response kinetics of phage MS2 depends not only on the turbidity level but on the type of particle causing the turbidity. Both amorphous biological solids (such as those found in secondary wastewater effluent) and amorphous chemical solids (such as aluminum or iron flocs formed after drinking water coagulation) were reported to effectively shield MS2 from inactivation by UV light at comparable turbidity levels, but to different degrees. Templeton et al. (2005) also showed that inorganic and organic suspended particles in solutions of similar turbidity levels do not have equal impacts on the UV inactivation of bacteriophage attached to the particles.

\section{SUMMARY AND CONCLUSIONS}

In summary, particle-associated viruses remain infective and survive for longer periods in the environment than dispersed (i.e. free-floating) viruses. Chemical and ultraviolet disinfection processes have been shown to be negatively impacted by some, but not all, types of particles. Particle type (size, structure, chemical composition) perhaps more so than turbidity or particle counts, often determines disinfection efficiency. Therefore, the disinfection of particle-laden waters (e.g. wastewater, unfiltered drinking water) should be carefully assessed on a case-bycase basis, to supplement the current standard operational approaches of monitoring turbidity or particle count levels in water and wastewater treatment.

Several conclusions can be drawn regarding the proper conduct of virus particleassociation studies. First, it is crucial to enumerate solids-associated viruses when analyzing environmental samples for virus concentrations. A number of different elution methods have been used for the enumeration of solids-associated viruses with varying degrees of success. In 
general, these methods have the common steps of addition of a chemical eluent combined with application of physical force to shear particles. Elution methods should be proven to provide reliable virus recovery and to not influence the viability of the virus in question. Second, no single phage or virus can represent the particle adsorption behavior of all viruses to all types of surfaces. Therefore, studies using model viruses should, if possible, use multiple virus types and select indicators that will be representative of a broad range of human enteric viruses. It is also important to select particles that will be representative of the type and concentration to be encountered in the particular treatment application of interest.

It is difficult to derive clear conclusions from previous literature reports of the impact of particle-associated viruses on disinfection due to a number of confounding factors. First, a number of studies do not report how or whether the disinfectant demand was taken into account, which is necessary to ensure that uniform disinfection doses are applied to parallel samples. Second, studies have considered water matrices consisting of seeded viruses in the presence of particles, without actively encouraging and confirming that the viruses become particleassociated. As such, conclusions from previous studies regarding the impact of suspended particles on virus disinfection efficiency may not always take into account the possibility of the survival of viruses that are attached onto or fully enmeshed within particles. 


\section{REFERENCES}

Atherton, J.G and Bell, S.S. (1983) Adsorption of Viruses on Magnetic Particles - I: Adsorption of MS2 Bacteriophage and the Effect of Cations, Clay and Polyelectrolyte. Water Research 17 (8), 943-948.

Babich, H. and Stotzky, G. (1980) Reductions in Inactivation Rates of Bacteriophages by Clay Minerals in Lake Water. Water Research 14 (2), 185-187.

Barbeau, B., Huffman, D., Mysore, C., Desjardins, R., and Prevost, M. (2004) Examination of Discrete and Confounding Effects of Water Quality Parameters During the Inactivation of MS2 Phages and Bacillus Subtilis Spores with Free Chlorine. Journal of Environmental Engineering and Science 3 (4), 255-268.

Batch, L., Schulz, C.R., and Linden, K.G. (2004) Evaluating Water Quality Effects on UV Disinfection of MS2 Coliphage. Journal of the American Water Works Association 96 (7), 75-87.

Berman, D., Rice, E.W., and Hoff, J.C. (1988) Inactivation of Particle-Associated Coliforms by Chlorine and Monochloramine. Applied and Environmental Microbiology 54 (2), 507-512.

Bitton, G., Henis, Y., and Lahav, N. (1972) Effect of Several Clay Minerals and Humic Acid on the Survival of Klebsiella aerogenes Exposed to Ultraviolet Irradiation. Applied Microbiology 23 (5), 870-874.

Bitton, G. and Mitchell, R. (1974) Effect of Colloids on the Survival of Bacteriophages in Seawater. Water Research 8 (4), 227-229.

Bitton, G., Fraxedas, R., and Gifford, G.E. (1979) Effect of Solar Radiation on Poliovirus: Preliminary Experiments. Water Research 13 (3), 225-228.

Bitton, G. (1980a) Introduction to Environmental Virology. Wiley-Interscience, Toronto, ON, pp.1-28, 67-90, 175-199.

Bitton, G. (1980b) Adsorption of Viruses to Surfaces: Technological and Ecological Implications. In Adsorption of Microorganisms to Surfaces, G. Bitton and K.C. Marshall (eds.), Wiley-Interscience, Toronto, ON, pp. 331-374.

Bixby, R.L. and O’Brien, D.J. (1979) Influence of Fulvic Acid on Bacteriophage Adsorption and Complexation in Soil. Applied and Environmental Microbiology 38 (5), 840-845.

Boardman, G.D. and Sproul, O.J. (1977) Protection of Viruses During Disinfection by Adsorption to Particulate Matter. Journal of the Water Pollution Control Federation 49, 1857-1861.

Borst, M. and Selvakumar, A. (2003) Particle-Associated Microorganisms in Stormwater Runoff. Water Research 37 (1), 215-223.

Boyce, D.S., Sproul, O.J., and Buck, C.E. (1981) The Effect of Bentonite Clay on Ozone Disinfection of Bacteria and Viruses in Water. Water Research 15 (6), 759-767.

Cairns, W.L., Sakamoto, G., Comair, C.B., and Gehr, R. (1993) Assessing UV Disinfection of a Physico-Chemical Effluent by Medium Pressure Lamps Using a Collimated Beam and Pilot Plant. Proceedings of the Water Environment Federation Specialty Conference on Planning, Design, and Operations of Effluent Disinfection Systems, Whippany, NJ, Water Environment Federation, Alexandria, VA.

Carter, M.J. (2005) Enterically Infecting Viruses: Pathogenicity, Transmission and Significance for Food and Waterborne Infection. Journal of Applied Microbiology 98, 1354-1380. 
Chauret, C., Armstrong, N., Fisher, J., Sharma, R., Springthorpe, S., and Sattar, S. (1995) Correlating Cryptosporidium and Giardia with Microbial Indicators. Journal of the American Water Works Association 87 (11), 76-84.

Chauret, C., Springthorpe, S., and Sattar, S. (1999) Fate of Cryptosporidium Oocysts, Giardia Cysts, and Microbial Indicators During Wastewater Treatment and Anaerobic Sludge Digestion. Canadian Journal of Microbiology 45, 257-262.

Christensen, J. and Linden, K.G. (2003). How particles affect UV light in the UV disinfection of unfiltered drinking water. Journal of the American Water Works Association 95 (4), 179-189.

Clancy, J.L., Hargy, T.M., Marchsll, M., and Dyksen, J. (1998) UV Light Inactivation of Cryptosporidium Oocysts. Journal of the American Water Works Association 90 (9), 92-102.

Coronell, O. and Marinas, B.J. (2004) Water Quality Effects on the Inactivation Kinetics of MS2 Phage with Free Chlorine. Proceedings of the American Water Works Association Water Quality Technology Conference, AWWA, Denver, CO.

Dietrich, J.P., Basagaoglu, H., Loge, F.J., and Ginn, T.R. (2003) Preliminary Assessment of Transport Processes Influencing the Penetration of Chlorine into Wastewater

Dowd, S.E., Pillai, S.D., Wang, S., and Corapcioglu, M.Y. (1998) Delineating the Specific Influence of Virus Isoelectric Point and Size on Virus Adsorption and Transport Through Sandy Soils. Applied and Environmental Microbiology 64 (2), 405-410.

Durbeej, B. and Eriksson, L.A. (2003) On the Formation of Cyclobutane Dimers in UVIrradiated DNA: Why are Thymines More Reactive? Photochemistry and Photobiology 78 (2), 159-167.

Ellender, R.D., Anderson, J.B., and Dunbar, R.B. (1987) Role of Sediment in the Persistence and Transport of Enteric Viruses in the Estuarine Environment. In Human Viruses in Sediments, Sludges, and Soils, V.C. Rao and J.L. Melnick (eds.), CRC Press, Boca Raton, FL, pp. 37-55.

Emerick, R.W., Loge, F.J., Thompson, D., and Darby, J.L. (1999) Factors Influencing Ultraviolet Disinfection Performance Part II: Association of Coliform Bacteria with Wastewater Particles. Water Environment Research 71 (6), 1178-1187.

Emerick, R.W., Loge, F.J., Ginn, T., and Darby, J.L. (2000) Modeling the Inactivation of Particle-Associated Coliform Bacteria. Water Environment Research 72 (4), 432-438.

Farrah, S.R. and Schaub, S.A. (1983) Viruses in Wastewater Sludge. In Viral Pollution of the Environment, G. Berg (ed.), CRC Press, Boca Raton, FL, pp. 147-161.

Farrah, S. (1987) Methods for Concentration and Recovery of Viruses from Wastewater Sludges. In Human Viruses in Sediments, Sludges, and Soils, V.C. Rao and J.L. Melnick (eds.), CRC Press, Boca Raton, FL, pp. 91-100.

Federal-Provincial-Territorial Committee on Drinking Water. (2003) Virological Quality of Drinking Water. Draft document for public comment.

Fuhs, G.W. and Taylor, D.H. (1982) Virus Uptake by Minerals and Soils. In Water Reuse, E.J. Middlebrooks (ed.), Ann Arbor Science, Ann Arbor, MI, pp. 603-640.

Gerba, C.P., Stagg, C.H., and Abadie, M.G. (1978) Characterization of Sewage SolidsAssociated Viruses and Behavior in Natural Waters. Water Research 12 (10), 805-812.

Gerba, C.P., Goyal, S.M., Hurst, C., and LaBelle, R.L. (1980) Type and Strain Dependence of Enterovirus Adsorption to Activated Sludge, Soils and Estuarine Sediments. Water Research 14 (9), 1197-1198.

Gerba, C.P. (1984) Applied and Theoretical Aspects of Virus Adsorption to Surfaces. Advances in Applied Microbiology 30, 133-168. 
Giese, N. and Darby, J. (2000) Sensitivity of Microorganisms to Different Wavelengths of UV Light: Implications on Modeling of Medium Pressure UV systems. Water Research 34 (16), 4007-4013.

Goyal, S.M. (1983) Indicators of Viruses. In Viral Pollution of the Environment, G. Berg (ed.), CRC Press, Boca Raton, FL, pp. 211-230.

Grabow, W.O.K. (2001) Bacteriophages: Update on Application as Models for Viruses in Water. Water SA 27 (2), 251-268.

Haas, C.N., Joffe, J., Anmangandla, U., and Jacangelo, J. (1996) The Effect of Water Quality on Disinfection Kinetics. Journal of the American Water Works Association 88 (3), 95-103.

Harrington, G.W., Xagoraraki, I., Assavasilavasukul, P., and Standridge, J.H. (2003) Effect of Filtration Conditions on Removal of Emerging Waterborne Pathogens. Journal of the American Water Works Association 95 (12), 95-104.

Havelaar, A.H., Furnose, K., and Hogeboom, W.M. (1986) Bacteriophages and indicator bacteria in human and animal faeces. Journal of Applied Bacteriology 60, 255-262.

Havelaar, A.H., Nieuwstad, T.J., Meulemans, C.C.E., and van Olphen, M. (1991) F-Specific RNA Bacteriophages as Model Viruses in UV Disinfection of Wastewater. Water Science and Technology 24 (2), 347-352.

Hejkal, T.W., Wellings, F.M., LaRock, P.A., and Lewis, A.L. (1979) Survival of Poliovirus Within Organic Solids During Chlorination. Applied and Environmental Microbiology 38 (1), 114-118.

Hejkal, T.W., Wellings, F.m., Lewis, A.L., and LaRock, P.A. (1981) Distribution of Viruses Associated with Particles in Wastewater. Applied and Environmental Microbiology 41 (3), 628-634.

Hoff, J.C. and Akin, E.W. (1983) Removal of Viruses from Raw Waters by Treatment Processes. In Viral Pollution of the Environment, G. Berg (ed.), CRC Press, Boca Raton, FL, pp. 53-75.

Hot, D., Legeay, O., Jacques, J., Gantzer, C., Caudrelier, Y., Guyard, K., Lange, M., and Andreoletti, L. (2003) Detection of Somatic Phages, Infectious Enteroviruses and Enterovirus Genomes as Indicators of Human Enteric Viral Pollution in Surface Water. Water Research 37 (19), 4703-4710.

Huck, P.M., Emelko, M.B., Coffee, B.M., Maurizio, D.D., and O’Melia, C.R. (2001) Filter Operation Effects on Pathogen Passage. American Water Works Association Research Foundation, Denver, CO.

Jolis, D., Lam, C., and Pitt, P. (2001) Particle Effects on Ultraviolet Disinfection of Coliform Bacteria in Recycled Water. Water Environment Research 73 (2), 233-236.

Kashinkunti, R.D., Linden, K.G., Shin, G.-A., Metz, D.H., Sobsey, M.D., Moran, M.C., and Samuelson, A.M. (2004) Investigating Multibarrier Inactivation for Cincinnati - UV, ByProducts, and Biostability. Journal of the American Water Works Association 96 (6), 114127.

Koizumi, Y. and Taya, M. (2002) Kinetic Evaluation of Biocidal Activity of Titanium Dioxide Against Phage MS2 Considering Interaction Between the Phage and Photocatalyst Particles. Biochememical Engineering Journal 12 (2), 107-116.

Kott, Y., Roze, N., Sperber, S., and Betzer, N. (1974) Bacteriophages as Viral Pollution Indicators. Water Research 8 (3), 165-171.

LeChevallier, M.W., Evans, T.M., and Seidler, R.J. (1981) Effect of Turbidity on Chlorination Efficiency and Bacterial Persistence in Drinking Water. Applied and Environmental Microbiology 42 (1), 159-167. 
LeChevallier, M.W., Norton, W.D., and Rose, J.B. (1991) Giardia and Cryptosporidium in Water Supplies. American Water Works Association Research Foundation, Denver, CO.

Lee, S., Nishida, K., Otaki, M., and Ohgaki, S. (1997) Photocatalytic Inactivation of Phage Q $\beta$ by Immobilized Titanium Dioxide Mediated Photocatalyst. Water Science and Technology 35 (11-12), 101-106.

Lewis, G.D. (1995) F-Specific Bacteriophages as an Indicator of Human Viruses in Natural Waters and Sewage Effluents in Northern New Zealand. Water Science and Technology 31 (5-6), 231-234.

Lipson, S.M. and Stotzky, G. (1983) Adsorption of Reovirus to Clay Minerals: Effects of CationExchange Capacity, Cation Saturation, and Surface Area. Applied and Environmental Microbiology 46 (3), 673-682.

Lipson, S.M. and Stotzky, G. (1984) Effect of Proteins on Reovirus Adsorption to Clay Minerals. Applied and Environmental Microbiology 48 (3), 525-530.

Lipson, S.M. and Stotzky, G. (1985) Infectivity of Reovirus Adsorbed to Homoionic and MixedCation Clays. Water Research 19 (2), 227-234.

Lipson, S.M. and Stotzky, G. (1987) Interactions Between Viruses and Clay Minerals. In Human Viruses in Sediments, Sludges, and Soils, V.C. Rao and J.L. Melnick (eds.), CRC Press, Boca Raton, FL, pp. 197-230.

Loge, F.J., Emerick, R.W., Thompson, D.E., Nelson, D.C., and Darby, J.L. (1999) Factors Influencing Ultraviolet Disinfection Performance Part I: Light Penetration to Wastewater Particles. Water Environment Research 71 (3), 377-381.

Malley, J.P., Petri, B.A., Hunter, G.V., Moran, D.M., Nadeau, M., and Leach, J. (2001). FullScale Implementation of Ultraviolet Disinfection in Groundwater Treatment Systems. AWWA, Denver, CO.

Mamane-Gravetz, H. and Linden, K.G. (2004) Impact of Particle Aggregated Microbes on UV Disinfection. Proceedings of the American Water Works Association Water Quality Technology Conference, San Antonio, TX.

Mamane-Gravetz, H. and Linden, K.G. (2005) Relationship Between Physicochemical Properties, Aggregation and UV Inactivation of Isolated Indigenous Spores in Water. Journal of Applied Microbiology 98 (2), 351-363.

Matson, J.V., Lowry, C.L., Chan, Y.M., and Whitworth, M.E. (1987) Physical and Chemical Characteristics of Sediments, Sludges, and Soils. In Human Viruses in Sediments, Sludges, and Soils, V.C. Rao and J.L. Melnick (eds.), CRC Press, Boca Raton, FL, pp. 3-20.

McCarthy, J.F. and Zachara, J.M. (1989) Subsurface Transport of Contaminants. Environmental Science and Technology 23 (5), 496-502.

Meng, Q.S. and Gerba, C.P. (1996) Comparative Inactivation of Enteric Adenovirus, Poliovirus, and Coliphages by Ultraviolet Irradiation. Water Research 30 (11), 2665-2668.

Meschke, J.S. and Sobsey, M.D. (1998) Comparative Adsorption of Norwalk Virus, Poliovirus 1 and F+ RNA Coliphage MS2 to Soils Suspended in Treated Wastewater. Water Science and Technology 38 (12), 187-189.

Moore, B.E., Sagik, B.P., and Malina, J.F. (1975) Viral Association With Suspended Solids. Water Research 9 (2), 197-203.

Moore, R.S., Taylor, D.H., Sturman, L.S., Reddy, M.M., and Fuhs, G.W. (1981) Poliovirus Adsorption by 34 Minerals and Soils. Applied and Environmental Microbiology 42 (6), 963 975. 
Nasser, A., Weinberg, D., Dinoor, N., Fattal, B., and Adin, A. (1995) Removal of Hepatitis A Virus (HAV), Poliovirus and MS2 Coliphage by Coagulation and High Rate Filtration. Water Science and Technology 31 (5-6), 63-68.

National Research Council Safe Drinking Water Committee (1977) Drinking Water and Health Volume 1. National Academy of Sciences, Washington, DC, pp. 88-111, 135-204.

Nieminski, E.C. and Ongerth, J.E. (1995) Removing Giardia and Cryptosporidium by Conventional Treatment and Direct Filtration. Journal of the American Water Works Association 87 (9), 96-106.

Nieuwstad, T.J. and Havelaar, A.H. (1994) The Kinetics of Batch Ultraviolet Inactivation of Bacteriophage MS2 and Microbiological Calibration of an Ultraviolet Pilot Plant. Journal of Environmental Science and Health 29 (9), 1993-2007.

Ohgaki, S. and Mongkonsiri, P. (1990) Effects of Floc-Virus Association on Chlorine Disinfection Efficiency. In Chemical Water and Wastewater Treatment, H.H. Hahn and R. Klute (eds.), Springer-Verlag, Berlin, pp. 75-84.

Oliver, B.G. and Cosgrove, E.G. (1975) The Disinfection of Sewage Treatment Plant Effluents Using Ultraviolet Light. Canadian Journal of Chemical Engineering 53, 170.

Ormeci, B. and Linden, K.G. (2002) Comparison of UV and Chlorine Inactivation of Particle and Non-Particle Associated Coliform. Water Science and Technology: Water Supply 2 (56), 403-410.

Parker, J.A. and Darby, J.L. (1995) Particle-Associated Coliform in Secondary Effluents: Shielding from Ultraviolet Light Disinfection. Water Environment Research 67 (7), 10651075.

Passantino, L., Malley, J., Knudson, M., Ward, R., and Kim, J. (2004) Effect of Low Turbidity and Algae on UV Disinfection Performance. Journal of the American Water Works Association 96 (6), 128-137.

Payment, P. and Franco, E. (1993) Clostridium Perfringens and Somatic Coliphages as Indicators of the Efficiency of Drinking Water Treatment of Viruses and Protozoan Cysts. Applied and Environmental Microbiology 59 (8), 2418-2424.

Qualls, R.G., Flynn, M.P., and Johnson, J.D. (1983) The Role of Suspended Particles in Ultraviolet Disinfection. Journal of the Water Pollution Control Federation 55 (10), 12801285.

Qualls, R.G., Ossoff, S.F., Chang, J.C.H., Dorfman, M.H., Dumais, C.M., Lobe, D.C., and Johnson, J.D. (1985) Factors Controlling Sensitivity in Ultraviolet Disinfection of Secondary Effluents. Journal of the Water Pollution Control Federation 57 (10), 1006-1011.

Quignon, F., Thomas, T., Gantzer, C., Huyard, A., and Schwartzbrod L. (1998) Virus Adsorption in a Complex System: An Experimentally Designed Study. Water Research 32 (4), 12221230.

Rao, V.C., Seidel, K.M., Goyal, S.M., Metcalf, T.G., and Melnick, J.L. (1984) Isolation of Enteroviruses from Water, Suspended Solids, and Sediments from Galveston Bay: Survival of Poliovirus and Rotavirus Adsorbed to Sediments. Applied and Environmental Microbiology 48 (2), 404-409.

Rao, V.C. (1987) Virus Association with Suspended Solids. In Human Viruses in Sediments, Sludges, and Soils, V.C. Rao and J.L. Melnick (eds.), CRC Press, Boca Raton, FL, pp. 57-75.

Rao, V.C. and Bitton, G. (1987) Methods for Recovering Viruses from Aquatic Sediments. In Human Viruses in Sediments, Sludges, and Soils, V.C. Rao and J.L. Melnick (eds.), CRC Press, Boca Raton, FL, pp. 21-36. 
Sakoda, A., Sakai, Y., Hayakuwa, K., and Suzuki, M. (1997) Adsorption of Viruses in Water Environment onto Solid Surfaces. Water Science and Technology 35 (7), 107-114.

Schaub, S.A. and Sagik, B.P. (1975) Association of Enteroviruses with Natural and Artificially Introduced Colloidal Solids in Water and Infectivity of Solids-Associated Virions. Applied Microbiology 30 (2), 212-222.

Schiffenbauer, M. and Stotzky, G. (1982) Adsorption of Coliphages T1 and T7 to Clay Minerals. Applied and Environmental Microbiology 43 (3), 590-596.

Scott, H.E., Liss, S.N., Farnood, R.R., and Allen, D.G. (2005) Ultraviolet Disinfection of Sequencing Batch Reactor Effluent: A Study of Physicochemical Properties of Microbial Floc and Disinfection Performance. Journal of Environmental Engineering and Science 4, S65-S74.

Shin, G.-A., Linden, K.G., and Sobsey, M.D. (2005) Low Pressure Ultraviolet Inactivation of Pathogenic Enteric Viruses and Bacteriophages. Journal of Environmental Engineering and Science 4, S7-S11.

Shin, G.A. and Sobsey, M.D. (1998). Reduction of Norwalk Virus, Poliovirus 1, and Coliphage MS2 by Monochloramine Disinfection of Water. Water Science and Technology 38, 151154.

Sobsey, M.D., Dean, C.H., Knuckles, M.E., and Wagner, R.A. (1980) Interactions and Survival of Enteric Viruses in Soil Materials. Applied and Environmental Microbiology 40 (1), 92101.

Sobsey, M.D. and Cromeans, T. (1985) Effects of Bentonite Clay Solids on Poliovirus Concentration from Water by Microporous Filter Methods. Applied and Environmental Microbiology 49 (4), 795-798.

Sobsey, M.D. and Hickey, A.R. (1985) Effects of Humic and Fulvic Acids on Poliovirus Concentration from Water by Microporous Filtration. Applied and Environmental Microbiology 49 (2), 259-264.

Stagg, C.H., Wallis, C., and Ward, C.H. (1977) Inactivation of Clay-Associated Bacteriophage MS-2 by Chlorine. Applied and Environmental Microbiology 33 (2), 385-391.

Stewart, M.H. and Olson, B.H. (1996) Bacterial Resistance to Potable Water Disinfectants. In Modeling Disease Transmission and Its Prevention by Disinfection, C.J. Hurst (ed.), Cambridge University Press, pp. 140-192.

Sundram, A., Donnelly, L., Ehlers, M.M., Vrey A., Grabow, W.O.K., and Bailey, I.W. (2002) Evaluation of F-RNA Coliphages as Indicators of Viruses and the Source of Faecal Pollution. Water SA Special Edition: WISA Proceedings.

Swaim, P.D., Cotton, C.A., and Jeyanayagam, S.S. (2005) Ultraviolet Disinfection. In Water Treatment Plant Design (Fourth Edition). E.E. Baruth (ed.), American Water Works Association and American Society of Civil Engineers, McGraw-Hill, Toronto, chapter 29.

Taylor, D.H., Moore, R.S., and Sturman, L.S. (1981) Influence of pH and Electrolyte Composition on Adsorption of Poliovirus by Soils and Minerals. Applied and Environmental Microbiology 42 (6), 976-984.

Templeton, M.R., Andrews, R.C., and Hofmann, R. (2005) Inactivation of Particle-Associated Viral Surrogates by Ultraviolet Light. Water Research 39 (15), 3487-3500.

Templeton, M.R., Andrews, R.C., and Hofmann, R. (2006) Impact of Iron Particles in Groundwater on the UV Inactivation of Bacteriophages MS2 and T4. Journal of Applied Microbiology 101 (3), 732-741. 
Thurston-Enriquez, J.A., Haas, C.N., Jacangelo, J., and Gerba, C.P. (2003) Chlorine Inactivation of Adenovirus Type 40 and Feline Calicivirus. Applied and Environmental Microbiology 69, 3979-3985.

United States Environmental Protection Agency. (1989) Surface Water Treatment Rule.

United States Environmental Protection Agency. (1999) Guidance Manual for Compliance with the Interim Enhanced Surface Water Treatment Rule: Turbidity Provisions. EPA 815-R-99010. Washington, DC.

Vaughn, J.M. and Metcalf, T.G. (1975) Coliphages as Indicators of Enteric Viruses in Shellfish and Shellfish Raising Estuarine Waters. Water Research 9 (7), 613-616.

Vilker, V.L., Meronek, G.C., and Butler, P.C. (1983) Interactions of Poliovirus with Montmorillonite Clay in Phosphate-Buffered Saline. Environmental Science and Technology 17 (10) 631-634.

Wait, D.A. and Sobsey, M.D. (1983) Method for Recovery of Enteric Viruses from Estuarine Sediments with Chaotropic Agents. Applied and Environmental Microbiology 46 (2), 379385.

Wellings, F.M., Lewis, A.L., and Mountain, C.W. (1976) Demonstration of Solids-Associated Virus in Wastewater and Sludge. Applied and Environmental Microbiology 31 (3), 354-358.

Wellings, F.M. (1987) Methods of Enterovirus Recovery from Different Types of Soils. In Human Viruses in Sediments, Sludges, and Soils, V.C. Rao and J.L. Melnick (eds.), CRC Press, Boca Raton, FL, pp. 129-139.

Whitby, G.E. and Palmateer, G. (1993) The Effect of UV Transmission, Suspended Solids and Photoreactivation on Microorganisms in Wastewater Treated with UV Light. Water Science and Technology 27 (3-4), 379-386.

Wiedenmann, A., Fischer, B., Straub, U., Wang, C.-H., Flehmig, B., and Schoenen, D. (1993) Disinfection of Hepatitis A Virus and MS-2 Coliphage in Water by Ultraviolet Irradiation: Comparison of UV-Susceptibility. Water Science and Technology 27 (3-4), 335-338.

Wright, H.B., Mackey, E., Cushing, R., and Tekippe, T. (2002) A Comparison of UV Disinfection for Drinking Water, Wastewater, and Reclaimed Wastewater. Proceedings of the Water Environment Federation Technical Exposition and Conference, Water Environment Federation, Alexandria, VA.

Wyn-Jones, A.P. and Sellwood, J. (2001) Enteric Viruses in the Aquatic Environment. Journal of Applied Microbiology 91, 945-962.

Xagoraraki, I., Harrington, G.W., Assavasilavasukul, P., and Standridge, J.H. (2004) Removal of Emerging Waterborne Pathogens and Pathogen Indicators by Pilot-Scale Conventional Treatment. Journal of the American Water Works Association 96 (5), 102-113.

Young, D.C. and Sharp, D.G. (1977) Poliovirus Aggregates and Their Survival in Water. Applied and Environmental Microbiology 33 (1), 168-177. 
TABLE 1. Bacteriophages used as model viruses in previous studies.

\begin{tabular}{|c|c|c|}
\hline Phage & Type of Study & Selected References \\
\hline \multirow[t]{5}{*}{ MS2 } & Use as viral indicator & Kott et al. (1974) \\
\hline & Chlorination & $\begin{array}{l}\text { Stagg et al. (1977), Barbeau et al. (2004), } \\
\text { Coronell and Marinas (2004) }\end{array}$ \\
\hline & Adsorption on particles & $\begin{array}{l}\text { Stagg et al. (1977), Bixby and O'Brien (1979), } \\
\text { Atherton and Bell (1983), Sakoda et al. (1997), } \\
\text { Dowd et al. (1998), Meschke and Sobsey } \\
(1998)\end{array}$ \\
\hline & UV disinfection & $\begin{array}{l}\text { Havelaar et al. (1991); Wiedenmann et al. } \\
\text { (1993); Nieuwstad et al. (1993); Batch et al. } \\
\text { (2004), Kashinkunti et al. (2004), Passantino et } \\
\text { al. (2004); Shin et al. (2005) }\end{array}$ \\
\hline & Filtration & $\begin{array}{l}\text { Nasser et al. (1995), Huck et al. (2001), } \\
\text { Harrington et al. (2003), Xagoraraki et al. } \\
(2004)\end{array}$ \\
\hline $\mathrm{T} 1$ & Adsorption on particles & Schiffenbauer and Stotzky (1982) \\
\hline $\mathrm{T} 2$ & Adsorption on particles & Moore et al. (1975) \\
\hline T4 & Adsorption on particles & Sakoda et al. (1997); Templeton et al. (2005) \\
\hline $\mathrm{T} 7$ & Adsorption on particles & $\begin{array}{l}\text { Bitton and Mitchell (1974), Moore et al. (1975), } \\
\text { Schiffenbauer and Stotzky (1982) }\end{array}$ \\
\hline \multirow[t]{3}{*}{$\mathrm{f} 2$} & Use as viral indicator & Kott et al. (1974) \\
\hline & Adsorption on particles & $\begin{array}{l}\text { Moore et al. (1975), Boyce et al. (1981), } \\
\text { Sakoda et al. (1997) }\end{array}$ \\
\hline & Ozonation & Boyce et al. (1981) \\
\hline$\varphi 11 \mathrm{M} 15$ & $\begin{array}{l}\text { Chlorination, adsorption on } \\
\text { particles }\end{array}$ & Babich and Stotzky (1980) \\
\hline \multirow[t]{2}{*}{$\mathrm{Q} \beta$} & Adsorption on particles & $\begin{array}{l}\text { Ohgaki and Mongkonsiri (1990), Sakoda et al. } \\
\text { (1997), Dowd et al. (1998) }\end{array}$ \\
\hline & Chlorination & Ohgaki and Mongkonsiri (1990) \\
\hline \multirow[t]{2}{*}{ PRD1 } & Adsorption on particles & Dowd et al. (1998) \\
\hline & UV disinfection & Kashinkunti et al. (2004); Shin et al. (2005) \\
\hline PM2 & Adsorption on particles & Dowd et al. (1998) \\
\hline $\begin{array}{l}\text { Somatic } \\
\text { coliphages }\end{array}$ & Use as viral indicators & $\begin{array}{l}\text { Vaughn and Metcalf (1975), Payment and } \\
\text { Franco (1993), Chauret et al. (1995), Chauret et } \\
\text { al. (1999), Sundram et al. (2002), Hot et al. } \\
\text { (2003) }\end{array}$ \\
\hline
\end{tabular}


TABLE 2. Model particles used in previous virus adsorption and treatment studies.

\begin{tabular}{|c|c|c|}
\hline Particle Class & Particle Type & Selected References \\
\hline \multirow[t]{11}{*}{ Clays } & Kaolinite & $\begin{array}{l}\text { Bitton et al. (1972), Moore et al. (1975), Babich } \\
\text { and Stotzky (1980), Sobsey et al. (1980), Moore et } \\
\text { al. (1981), Schiffenbauer and Stotky (1982), Lipson } \\
\text { and Stotzky (1983), Lipson and Stotzky (1984), } \\
\text { Lipson and Stotzky (1985), Ohgaki and } \\
\text { Mongkonsiri (1990), Sakoda et al. (1997), Meschke } \\
\text { and Sobsey (1998), Barbeau et al. (2004) }\end{array}$ \\
\hline & Montmorillonite & $\begin{array}{l}\text { Bitton et al. (1972), Bitton and Mitchell (1974), } \\
\text { Schaub and Sagik (1975), Babich and Stotzky } \\
\text { (1980), Moore et al. (1981), Taylor et al. (1981), } \\
\text { Schiffenbauer and Stotzky (1982), Lipson and } \\
\text { Stotzky (1983), Vilker et al. (1983), Lipson and } \\
\text { Stotzky (1984), Lipson and Stotzky (1985), } \\
\text { Passantino et al. (2004) }\end{array}$ \\
\hline & Nontronite & Bitton et al. (1972), Bitton et al. (1979) \\
\hline & Bentonite & $\begin{array}{l}\text { Moore et al. (1975), Stagg et al. (1977), Sobsey et } \\
\text { al. (1980), Boyce et al. (1981), Sobsey and } \\
\text { Cromeans (1985), Meschke and Sobsey (1998) }\end{array}$ \\
\hline & Dickite & Bitton et al. (1972), Moore et al. (1981) \\
\hline & Hectorite & Bitton et al. (1972) \\
\hline & Halloysite & Bitton et al. (1972), Moore et al. (1981) \\
\hline & Attapulgite & Babich and Stotzky (1980), Moore et al. (1981) \\
\hline & Vermiculite & Babich and Stotzky (1980) \\
\hline & Magnetite & Atherton and Bell (1983) \\
\hline & Dolomite & Moore et al. (1981) \\
\hline \multirow[t]{6}{*}{ Organics } & Dry dog food & Moore et al. (1975), Schaub and Sagik (1975) \\
\hline & Wastewater solids, sludge & $\begin{array}{l}\text { Moore et al. (1975), Gerba et al. (1980), Ohgaki } \\
\text { and Mongkonsiri (1990) }\end{array}$ \\
\hline & Fulvic acid & Bixby and O'Brien (1979) \\
\hline & Humic acid & $\begin{array}{l}\text { Bitton et al. (1972), Babich and Stotzky (1980), } \\
\text { Sobsey and Hickey (1985), Nasser et al. (1995) }\end{array}$ \\
\hline & Fecal homogenate & Wellings et al. (1976) \\
\hline & Organic 'muck' soil & $\begin{array}{l}\text { Sobsey et al. (1980), Moore et al. (1981), Meschke } \\
\text { and Sobsey (1998) }\end{array}$ \\
\hline
\end{tabular}


TABLE 3. Isoelectric points of waterborne viruses. Virus strains are given in parentheses. More than one $\mathrm{pI}$ value shown for the same virus strain reflects results of different pI measurement methods. Adapted from Fuhs and Taylor (1982), Gerba (1984), and Sakoda et al. (1997).

\begin{tabular}{lcc}
\hline Virus & Virus Type & Isoelectric point (pI) \\
\hline Reovirus Type 3 & Mammalian & $3.8,4.0$ \\
Vaccinia & Mammalian & $3.9,4.8$ \\
Coxsackievirus A21 & Mammalian & $4.8,6.1$ \\
Poliovirus Type 1 (Brunhilde) & Mammalian & $4.5,7.0$ \\
Poliovirus Type 1 (Mahoney) & Mammalian & 8.2 \\
Echovirus Type 1 (V248) & Mammalian & 5.0 \\
Echovirus Type 1 (V212) & Mammalian & 6.4 \\
Tobacco mosaic virus & Plant & $3.8,4.1$ \\
MS2 & Bacterial Phage & 3.9 \\
T2 & Bacterial Phage & 4.2 \\
T4 & Bacterial Phage & 4.2 \\
Q $\beta$ & Bacterial Phage & $4.1,5.3$ \\
Fr & Bacterial Phage & 9.0 \\
\hline
\end{tabular}


TABLE 4. Isoelectric points of various solid surfaces. Adapted from Gerba (1984).

\begin{tabular}{lcc}
\hline Solid & Solid Type & Isoelectric point (pI) \\
\hline Quartz & Mineral & $2.0-3.5$ \\
Kaolinite & Mineral & $2.0-4.6$ \\
Montmorillonite & Mineral & $<2.5$ \\
Allophane & Mineral & 6.5 \\
Tenorite & Mineral & 9.5 \\
Humic matter & Organic & $<3.0$ \\
Cellulose nitrate & Filter material & $1.5-2.0$ \\
Epoxy fiberglass & Filter material & $1.0-1.5$ \\
Fiberglass-asbestos & Filter material & 3.0 \\
\hline
\end{tabular}


TABLE 5. Waterborne virus groupings by adsorptive behavior to soil, as proposed by Gerba (1984). Virus strains are given in parentheses.

\begin{tabular}{ccc}
\hline Group 1 & Group 2 & Group 3 \\
\hline Coxsackievirus B4 (V216) & Poliovirus Type 1 (LSc) & fr \\
Coxsackievirus B4 (V240) & Echovirus 7 (Wallace) & \\
Echovirus 1 (Farouk) & Coxsackievirus B3 (Nancy) & \\
Echovirus 1 (V212) & T4 & \\
Echovirus 1 (V-39) & T2 & \\
Echovirus 1 (V248) & & \\
$\varphi X 174$ & & \\
MS2 & & \\
\hline
\end{tabular}


TABLE 6. Location of virus bonding on clay surfaces, as determined using electron microscopy. Adapted from Lipson and Stotzky (1987).

\begin{tabular}{|c|c|c|}
\hline Virus & Adsorbent & $\begin{array}{l}\text { Mode of attachment } \\
\text { (virus to clay) }\end{array}$ \\
\hline Coxsackievirus A9 & Montmorillonite & Virion $^{\mathrm{a}}$ to Face ${ }^{\mathrm{b}}$ \\
\hline Coliphage $\mathrm{T} 1, \mathrm{~T} 7$ & Kaolinite & Tail $^{c}$ to Edge ${ }^{\mathrm{d}}$ \\
\hline Coliphage T1, T7 & Montmorillonite & Tail to Edge \\
\hline Coliphage $\mathrm{T} 1$ & Montmorillonite & $\begin{array}{l}\text { Tail to Face } \\
\text { Head to Face }\end{array}$ \\
\hline Coliphage T4 & Celkate T-21 & Head to Face \\
\hline Tobacco mosaic virus & Kaolinite & Virion to Face \\
\hline Reovirus Type 3 & Kaolinite & Virion to Face \\
\hline
\end{tabular}

\footnotetext{
${ }^{a}$ Bacteriophage attached by its head

${ }^{\mathrm{b}}$ Planar surface of clay mineral

${ }^{\mathrm{c}}$ Bacteriophage attached by its tail

${ }^{\mathrm{d}}$ Edge of clay mineral
} 
TABLE 7. Various eluents and physical treatments used in previous studies for the recovery of viruses adsorbed to wastewater sludges, aquatic sediments, and soils. Adapted from Farrah (1987), Rao and Bitton (1987), and Wellings (1987).

\begin{tabular}{|c|c|c|}
\hline Particle Type & Eluents & Physical Treatments \\
\hline Sludge Flocs & $\begin{array}{l}\text { - } 10 \% \text { Beef extract } \\
\text { - } 3 \% \text { Beef extract } \\
\text { - } 1 \% \text { Skim milk } \\
\text { - } \text { Typtose phosphate broth } \\
\text { - } 0.05 \mathrm{M} \text { Glycine (pH 11.5) } \\
\text { - } 4 \mathrm{M} \text { Urea and } 1 \mathrm{M} \text { lysine (pH 9.0) } \\
\text { - } \quad \text { Base to produce } \mathrm{pH} 9.0 \\
\end{array}$ & $\begin{array}{l}\text { - Shaking by hand } \\
\text { - Blending } \\
\text { - Sonication } \\
\text { - Stirring }\end{array}$ \\
\hline Aquatic Sediments & $\begin{array}{l}\text { - } \text { Glycine-EDTA (pH 11.0) } \\
\text { - Urea-lysine (pH 9.0) } \\
\text { - } \text { Beef extract-sodium nitrate } \\
\text { - } 3 \% \text { Beef extract ( } \mathrm{pH} 10.5) \\
\text { - } 6 \% \text { Beef extract ( } \mathrm{pH} 9.0) \\
\text { - } \text { Casein-lecithin } \\
\text { - } 10 \% \text { Tryptose phosphate broth }\end{array}$ & $\begin{array}{l}\text { - Vortexing } \\
\text { - Shaking } \\
\text { - Centrifugation }\end{array}$ \\
\hline Soils & $\begin{array}{l}\text { - } \text { Glycine-EDTA (pH 11.5) } \\
\text { - } 10 \% \text { Beef extract (pH 7.0) } \\
\text { - } 3 \% \text { Beef extract (pH 10.5) } \\
\text { - } \quad \text { Casein-glycine (pH 9.0) }\end{array}$ & $\begin{array}{l}\text { - Magnetic stirrer } \\
\text { - Shaking by hand } \\
\text { - Centrifugation }\end{array}$ \\
\hline
\end{tabular}

